\title{
NEW PROOFS OF WEIGHTED POWER MEAN INEQUALITIES AND MONOTONICITY FOR GENERALIZED WEIGHTED MEAN VALUES
}

\author{
Feng Qi, Jia-Qiang Mei, DA-Feng Xia and Sen-Lin Xu
}

\begin{abstract}
In the article, a new proof of the weighted power mean inequalities is given using Cauchy-Schwarz-Buniakowski's inequality, and another two simple and short proofs of monotonicity for the generalized weighted mean values with two parameters are showed.
\end{abstract}

Mathematics subject classification (1991): 26D15, 26A48.

Key words and phrases: Inequality, weighted mean, power mean, Cauchy-Schwarz-Buniakowski's inequality, monotonicity, generalized weighted mean values.

\section{REFERENCES}

[1] H. ALZER, A proof of the arithmetic mean-geometric mean inequlity, Amer. Math. Monthly 103 (1996), 585.

[2] P. S. Bullen, D. S. Mitrinović, And P. M. Vasić, Means and Their Inequalities, D. Reidel Publ. Company, Dordrecht/Boston/Lancaster/Tokyo, 1988.

[3] Ji-Chang Kunng, Applied Inequalities, 2nd edition, Hunan Education Press, Changsha, China, 1993. (Chinese)

[4] E. B. LeACh AND M. C. Sholander, Extended mean values, Amer. Math. Monthly 85 (1978), 84-90.

[5] LÁsZLó LosoncZI, Inequalities for integral mean values, J. Math. Anal. Appl. 61 (1977), 586-606.

[6] D. S. Mitrinović, Analytic Inequalities, Springer-Verlag, Berlin, 1970.

[7] D. S. Mitrinović, J. E. PeČARIC, AND A. M. FinK, Classical and New Inequalities in Analysis, Kluwer Academic Publishers, 1993.

[8] J. PEČARIĆ, Nejednakosti, Element, Zagreb, 1996.

[9] J. PeČARIĆ, FEng QI, V ŠImić, AND SEN-Lin Xu, Refinements and extensions of an inequality, III, J. Math. Anal. Appl. 227 (1998), no. 2, 439-448.

[10] J. PeČARIĆ AND S. VAROŠANEC, A new proof of the arithmetic mean-the geometric mean inequlity, J. Math. Anal. Appl. 215 (1997), 577-578.

[11] FEng QI, Generalized weighted mean values with two parameters, Proc. Roy. Soc. London Ser. A 454 (1998), no. 1978, 2723-2732.

[12] FENG QI, On a two-parameter family of nonhomogeneous mean values, Tamkang J. Math. 29 (1998), no. $2,155-163$.

[13] FEng QI, Generalized abstracted mean values, Journal of Inequalities in Pure and Applied Mathematics 1 (2000), no. 1, Article 4. http://jipam.vu.edu.au/v1n1/013_99.html. RGMIA Research Report Collection 2 (1999), no. 5, Article 4. http://rgmia.vu.edu.au/v2n5.html.

[14] FENG QI, Logarithmic convexities of the extended mean values, RGMIA Research Report Collection 2 (1999), no. 5, Article 5. http://rgmia.vu.edu.au/v2n5.html.

[15] FENG QI AND QIU-MING LUO, A simple proof of monotonicity for extended mean values, J. Math. Anal. Appl. 224 (1998), 356-359.

[16] Feng QI, JiA-QIANG MeI, AND SEN-Lin XU, Other proofs of monotonicity for generalized weighted mean values, RGMIA Research Report Collection 2 (1999), no. 4, Article 6. http://rgmia.vu.edu.au/v2n4.html.

[17] Feng Qi, Sen-Lin Xu, and LoKenath Debnath, A new proof of monotonicity for extended mean values, Intern. J. Math. Math. Sci. 22 (1999), no. 2, 415-420. 
[18] Feng QI AND SEn-Lin Xu, Refinements and extensions of an inequality, II, J. Math. Anal. Appl. 211 (1997), 616-620.

[19] Feng QI AND SEn-Lin Xu, The function $\left(b^{x}-a^{x}\right) / x$ : Inequalities and properties, Proc. Amer. Math. Soc. 126 (1998), no. 11, 3355-3359.

[20] Feng QI AND ShI-QIn Zhang, Note on monotonicity of generalized weighted mean values, Proc. Roy. Soc. London Ser. A 455 (1999), no. 1989, 3259-3260.

[21] Da-Feng Xia, Sen-Lin Xu, AND Feng QI, A proof of the arithmetic mean-geometric meanharmonic mean inequalities, RGMIA Research Report Collection 2 (1999), no. 1, Article 10, 99-102. http://rgmia.vu.edu.au/v2n1.html.

[22] REN-ER YANG AND DONG-Ji CAO, Generalizations of the logarithmic mean, J. Ningbo Univ. 2 (1989), no. $2,105-108$. 